\title{
End of life
}

\section{Expert care and support, not physician-hastened death}

Joseph C. Masdeu, MD, PhD, Allen J. Aksamit, MD, Alan C. Carver, MD, Kathleen M. Foley, MD, Joseph S. Kass, MD, JD, Raymond A. Martin, MD, Elizabeth A. McCusker, MB, BS, Michael P. McQuillen, MD, MA, Raja Mehanna, MD, Richard Payne, MD,† Stephen J. Victor, MD, and Steven Warach, MD, PhD

Neurology ${ }^{\circledR}$ 2019;93:729-734. doi:10.1212/WNL.0000000000008356

\section{Abstract}

In legal physician-hastened death, a physician prescribes medication with the primary intent of causing the death of a willing terminally ill patient. This practice differs radically from palliative sedation, intended to relieve a patient's suffering rather than cause a patient's death. In this position paper, we argue that the practice of physician-hastened death is contrary to the interests of patients, their families, and the sound ethical practice of medicine. Therefore, the American Academy of Neurology should advise its members against this practice, as it had done until 2018.

\section{Introduction}

A February 2018 official statement of the American Academy of Neurology (AAN), authored by the Ethics, Law, and Humanities (ELH) Committee, reads as follows:

The AAN has decided to retire its 1998 position on "Assisted suicide, euthanasia, and the neurologist" and to leave the decision of whether to practice or not to practice LPHD [lawful physician hastened death] to the conscientious judgment of its members acting on behalf of their patients. ${ }^{1}$

This statement appears to simply withdraw the AAN from taking a stance on the crucial issue of whether a physician may prescribe medication with the direct goal of causing death.

\section{The new position of the AAN on physician-assisted suicide (PAS) is not really neutral}

On first read, the AAN's decision to leave "the decision of whether to practice or not to practice LPHD to the conscientious judgment of its members" seems most reasonable. However, atrocities have been committed throughout history by people, including physicians, who made a misguided conscientious judgment. ${ }^{2,3}$ As Immanuel Kant has argued, ${ }^{4}$ a conscientious judgment has to be guided by sound ethical principles. Furthermore, the wording of the ELH statement implies that the previous AAN position was coercive, as laws are. On the contrary, when until very recently, the AAN advised its members against using medical means to cause death, it enunciated an ethical principle, not a legal one. Under its previous guidance, the AAN made plain that although the organization would not discipline members practicing physicianassisted suicide, it still considered the practice unequivocally unethical.

\section{Correspondence}

Dr. Masdeu

jcmasdeu@

houstonmethodist.org 


\section{Glossary}

AAN = American Academy of Neurology; ELH = Ethics, Law, and Humanities; LPHD = lawful physician-hastened death; PAS $=$ physician-assisted suicide.

With this recent change in position, the AAN is implicitly condoning lawful physician-hastened death (LPHD) as ethical. Accepting LPHD as ethical is misguided and prioritizes respect for patient autonomy over the physician's universal duty to do no harm, a principle LPHD violates by intentionally hastening a patient's death. Although an important principle of medical ethics, respect for autonomy does not automatically trump nonmaleficence (not harming a patient) in many ethically challenging situations. For example, patients with mental illness are often institutionalized and treated against their will in an effort to protect them and improve their condition. Physicians are ethically obligated to refuse harmful medical or surgical interventions even when patients demand them. Such actions are not examples of paternalism but rather are the hallmarks of the sound, ethical practice of medicine. ${ }^{5}$ Physicians possess effective techniques to allow the process of natural death to unfold while effectively alleviating the suffering of the terminally ill without violating the fundamental ethical prohibition against intentionally causing or hastening a patient's death. The data referenced in the ELH Statement do not justify this radical change in AAN policy. However, this policy change endangers the welfare of our patients, our patients' families, and our profession, as other professional societies, like the American College of Physicians, have recognized. ${ }^{6}$

\section{LPHD opens the door to physician abuses}

Denying a physician the right to shorten life upon patient request may appear cruel and insensitive. However, ethical principles forbidding this practice exist to protect vulnerable individuals. In jurisdictions where both PAS and euthanasia are legal, the requirements and guidelines to restrict PAS only to patients who request it appear to fall short of adequately protecting against involuntary decisions. ${ }^{7}$ Breaches of protective safeguards have been documented, ${ }^{8,9}$ and interviews with physicians in some of those jurisdictions disclose a pervasive complacency with regard to violations of guidelines requiring patient consent as a prerequisite to performing LPHD. $^{10}$

Proponents of LPHD argue that patient autonomy should be respected. However, respect for autonomy does not obligate physicians to acquiesce to unethical behavior in the name of advancing patient autonomy. Physicians are obligated to assure that patients make decisions free of coercion, misinformation, or inaccurate assessments of their situation, as may occur when the patient experiences depression. Physicians are unable to evaluate all of these factors accurately unless they know their patients well. Guidelines in jurisdictions allowing LPHD are intended to prevent events like the one described in the brief report ${ }^{11}$ that sparked the discussion on euthanasia in the late 1980s, in which a US gynecology resident killed a young woman he had met for the first time only a few minutes before while on rounds that evening. Regarding the role of physicians in LPHD, data from LPHD-legal jurisdictions are illuminating. From 2000, when coding of prescribers began, through 2016, 374 physicians in Oregon (fewer than $4 \%$ of all licensed physicians in the state) wrote prescriptions for assisted suicide, with 110 writing 2 to 5 prescriptions, 24 writing 6 to 19 , and 10 writing more than 20 prescriptions. ${ }^{12}$ LPHD seems to cluster around a small group of physicians, either because these physicians are more likely to suggest the practice of LPHD or because patients requesting LPHD are referred to them. If these physicians initiate the recommendation for LPHD to their patients, then these physicians become the main drivers of LPHD, regardless of their patients' acquiescence. If patients are referred to these providers with whom they do not have a preexisting relationship, they may find themselves in the care of physicians who are unaware of issues that an ongoing relationship would clarify. With LPHD the same physician is both healer and agent of death, roles that are fundamentally conflicted and irreconcilable. Society should not condone suicide or killing by anyone, especially not at the hands of physicians. To preserve patients' safety, professionals entrusted with healing should not perform functions intended to cause death.

\section{LPHD: A new source of guilt for our patients}

Many neurologic disorders disable our patients, leaving them prone to feeling a burden on others. If LPHD becomes more acceptable and more expected, patients may feel compelled to turn to LPHD to fulfill a perceived obligation to their families or other caretakers. Jurisdictions where either PAS or euthanasia has been legalized have experienced a year on year increase in the frequency of assisted suicides. ${ }^{12,13}$ Normalizing LPHD has the potential to place competent neurologic patients requiring high levels of care in the unacceptable position of feeling guilty about not hastening their own deaths.

\section{LPHD: Particularly dangerous for incompetent patients}

The acceptance of LPHD may uniquely compromise patients with either dementia or psychiatric disorders. ${ }^{14,15}$ If competent 
patients can request to shorten their lives, the inability of incompetent ones to do likewise may be construed as discrimination on the basis of their disability. The logical next step is to leave to others the decision about hastening death. This logical progression from the right to die of the legally competent to the legally incompetent is how events have unfolded in the Netherlands, where the number of physician-assisted suicide or euthanasia events on the basis of either mental health disorders or dementia has risen 10 -fold from 2010 to 2016 . $^{13}$

\section{LPHD undermines the quality of palliative and psychological care}

A section of the 2018 ELH Committee position statement reads "the committee recognizes that palliative care interventions may not be universally effective for all terminally ill patients who may seek hastened death assistance from AAN members, particularly with spiritual or existential suffering" (our emphasis). While LPHD proponents try to convince the public that legalized assisted death prevents unbearable physical pain, ${ }^{16}$ the reality in jurisdictions where LPHD is legal is that LPHD occurs mostly for reasons of psychological or existential suffering. ${ }^{12,17}$ In 2018 as in previous years, the 3 most frequently reported end-of-life concerns motivating LPHD in Oregon were loss of autonomy (92\%), decreasing ability to participate in activities that made life enjoyable (91\%), and loss of dignity (67\%). ${ }^{18}$ Yet only 2 out of 249 patients receiving prescriptions for LPHD were referred for psychiatric or psychological evaluation. ${ }^{18}$ LPHD is an inhumane way of dealing with the very problems precipitating the decision to seek LPHD, as illustrated particularly well by experience in the Netherlands. A Dutch Regional Head of Palliative Care observed: "I think [...] that euthanasia is sometimes too easily provided. There is [...] such inability to deal with death. It is a bit like you can order it." ${ }^{19}$ A Dutch oncologist stated, "Palliative care is not very well organised. You could say that there is no professional organisation of palliative care in the Netherlands." Among patients dying of cancer or organ failure in the Netherlands, only $25 \%$ received palliative care services in the last 3 months of life, compared to an average of $65 \%$ in 2 other Western European countries not allowing LPHD. ${ }^{20}$

The availability of LPHD undermines the quality of psychiatric care not only for people who are severely depressed, ${ }^{21}$ who some consider LPHD candidates, ${ }^{15}$ but also for patients with somatic terminal disorders. Eighty percent of patients with cancer who complete suicide have a mood disorder, yet treatment of depression reduces suicidal ideation in this population. ${ }^{22}$ Once adequately treated, including through the use of ongoing dignity-conserving care, ${ }^{23}$ these patients often change their minds about suicide. ${ }^{22}$ Depression is notoriously underrecognized and undertreated in the terminally ill. Patients, families, and members of the medical team may misinterpret the symptoms of depression as a sign of a demoralizing cognitive decline rather than of a potentially treatable condition. ${ }^{21}$

\section{Caregivers' perception of LPHD and of the LPHD-dealing physician}

Participating in LPHD may well create in caregivers either a guilt feeling ${ }^{24}$ or the belief that human life can be ended at will. When this outlook spreads, the elderly, the sick, and the handicapped become potential targets of those less scrupulous. ${ }^{25}$

The Right to Die movement paints natural death as frightening and demeaning. The very name the movement uses for LPHD, "death with dignity," conveys this marketing strategy. However, an alternative narrative about natural death deserves to be heard. Without LPHD, a patient's family can rest assured that a loved one's death was not the product of a physician-driven decision to hasten death but rather the result of nature taking its course. This type of death is true "death with dignity." In terminal illness, the effort made by patients and their families is often an ode to the human spirit and to the value of family ties. Tracy Grant, Managing Editor of the Washington Post, provided an arresting account of her experience with her dying husband in her article "I was my husband's caregiver as he was dying of cancer. It was the best seven months of my life." 26 As reflected in the title and expanded in the article, the author was a most dedicated caregiver who helped her husband die peacefully. Publicizing such experiences is important because Ms. Grant's experience mirrors the experiences of many of our patients and their families.

As neurologists, we are in a unique position to offer our colleague physicians as well as the families of patients with neurologic injuries our expertise in neurologic prognostication, helping in weighing the pros and cons of a therapeutic intervention at the end of life. For a suffering patient, we can advise on more effective means to alleviate pain, including the appropriate use of palliative sedation, an intervention whose goal is to alleviate suffering even if the patient's life is shortened as a by-product of the intervention. ${ }^{27}$ Our advice can forestall needless hardships for the patient at the end of life and help prevent the huge cost of life-prolonging measures that will have no effect on the patient's chances of recovery.

However, once LPHD is in place, clarity at the end of life is lost. The Oregon Death with Dignity Act forbids calling suicide what has universally been understood as suicide - the taking of one's life voluntarily and intentionally. ${ }^{28}$ Even the ELH Committee position statement is muddled: "The committee chose LPHD in lieu of PAS [physician-assisted-suicide] to remove any ambiguity regarding patient motivation, which is not to commit suicide per se, but to hasten death in order to relieve suffering." However, the relief of suffering through death motivates people to commit suicide, and suicide, by definition, hastens death. The Statement continues, "the committee considers LPHD to be morally distinctive from other medical interventions that do or may hasten death such as the withdrawal of life-sustaining treatments, palliative sedation, and 
euthanasia." ${ }^{1}$ So, what is LPHD? Nowhere in the ELH Committee position statement is LPHD explicitly defined. From other contexts, it appears that LPHD refers to "the prescription of medication by a physician in response to the request of a terminally ill patient that is administered by the patient and intended to relieve intractable patient suffering by causing death." (emphasis added). Thus, as recognized in the ELH Committee position statement, ${ }^{1}$ LPHD is radically different from either withdrawing life-sustaining treatment or palliative sedation, both of which are ethically acceptable. ${ }^{27}$ Palliative sedation is intended to relieve suffering, not end life, using a drug protocol that differs from LPHD. ${ }^{27}$

\section{LPHD turns our profession into a danger for society}

Perhaps the most concerning aspect of the recent AAN shift is the message this change sends to neurologists: It is acceptable, in some instances, to use medical means to shorten a patient's life. Physicians have always been aware of how dangerous it is to shorten patients' lives in difficult situations and have set guidelines to avoid this practice. In fact, the original Hippocratic Oath forbade such behavior: "I will neither give a deadly drug to anybody who asked for it, nor will I make a suggestion to this effect." 29 Thus, this change in the AAN's position radically redefines the physician's societal role. It may have unintended, undesirable consequences, since the bottom of a slippery slope may not be apparent from the top. For example, the Netherlands experience provides a cautionary tale of such a slippery slope, demonstrating how the lifting of the societal ethical taboo against physician-assisted killing laid the groundwork for legalizing euthanasia. A 1984 Dutch judicial decision allowing assisted suicide was followed by a law allowing euthanasia for patients with diminished capacity in $2002 .^{10}$

Oregon has not moved from LPHD to euthanasia, possibly because Americans generally do not support LPHD. Right to Die activists are working hard to change this outlook and are targeting medical professional societies as part of their campaign. ${ }^{30}$ Furthermore, there is ample experience on how an initially voluntary measure that policy makers believe is money-saving becomes enforceable some time later. Viewing LPHD as a money-saving opportunity is neither an artifact of the past nor confined to countries across the Atlantic. Based on the LPHD experience in Belgium and the Netherlands, a recently published Canadian cost analysis reckons that implementing "medical assistance in dying" could reduce annual health care spending across Canada by between $\$ 34.7$ and $\$ 138.8$ million, exceeding the \$1.5-\$14.8 million in direct costs associated with its implementation. ${ }^{31}$ Voices have already been raised in the United States calling for physicians to be obligated to participate in practices for which they may have a conscientious objection. ${ }^{32}$
Dr. Leo Alexander, who studied the change in attitudes towards the ill that took place in Germany at the beginning of the 20th century, laying the foundations for subsequent events in the 1930s, described what the top of the slippery slope looked like: "Whatever proportion those crimes finally assumed, it became evident to all who investigated them that they started from small beginnings [...] merely a subtle shift in emphasis in the basic attitude of the physicians. It started with the acceptance of the attitude, basic in the euthanasia movement, that there is such a thing as life not worthy to be lived." 25 Those unaware of the mistakes of the past are bound to repeat them. LPHD is defended as a means to respect the autonomous persons' right to self-determination. ${ }^{33}$ However, to facilitate the will of a few (less than $0.4 \%$ of all deaths are LPHD in American LPHD jurisdictions), ${ }^{9}$ it is not justifiable to place many people at risk, particularly those who are most vulnerable.

\section{The February 2018 ELH Committee Position Statement does not represent the opinion of the majority of AAN members}

The Position Statement mentions the 2014 AAN PhysicianAssisted Suicide Survey, a survey not sent to a random sample of AAN members. Rather, approximately one-half of the surveyed neurologists lived in the minority of states allowing PAS. Furthermore, the Statement quotes the most extreme figure in support of LPHD. Responding to a hypothetical scenario, "more than $70 \%$ of responding members in PAS-lawful states endorsed LPHD as an ethically permissible behavior." However, in response to the more relevant question for the purpose of the Position Statement, "Do you believe the AAN's position on PAS conflicts with your professional obligation to your patients? (Note: PAS is ethically prohibited in the current AAN position statement)," 50.4\% responded No or Uncertain in states where PAS is legal, whereas $69.5 \%$ responded No or Uncertain in states where PAS is illegal. Even if this survey had supported LPHD — and it did not-the results would have been a poor foundation on which to base a radical change in position, since the survey was sent to only 802 AAN members, $50 \%$ of whom lived in states allowing LPHD, and had only a $30 \%$ response rate.

Committee dynamics are complex. ${ }^{34,35}$ Yet, it is remarkable that "the Ethics, Law and Humanities Committee [...] unanimously recommended to the Boards of the AAN and the AAN Institute that the 1998 position be retired." ${ }^{34,35}$ Data from the AAN survey just cited suggest that the views of the ELH committee do not represent the views of the AAN membership at large. AAN members should become involved in the committee structure of their largest professional organization if they want their views to be heard. Also, this is a reminder to AAN leadership to foster an open policy in the composition of committees, so that a diversity of views may be represented. 


\section{Conclusion}

As the largest professional organization of neurologists in the world, the AAN bears a great deal of responsibility for shaping attitudes and approaches when providing ethical advice to neurologists. When proffering ethical guidance, the AAN should base its recommendations on established ethical principles. The AAN has justified its shift in attitude about LPHD as a response to the legalization of PAS in some states. However, US history exemplifies how practices once legal in some states have later been abandoned as abhorrent to human dignity. Ethical principles do not change because state laws change. Physician actions with the primary intent to cause or hasten a patient's death are intrinsically wrong and ethically indefensible. While we respect the judgment of the individuals in the various AAN committees who vetted the change in policy, as committed AAN members we need to record our strong opposition to this policy change. We urge the AAN to reconsider this decision. Our specialty provides us with the tools to have a keen understanding of the somatic and psychological needs of terminally ill patients and the means to alleviate their suffering without intentionally hastening their death.

\section{Acknowledgment}

Richard Payne, MD, died after the first submission of this article.

\section{Study funding}

No targeted funding reported.

\section{Disclosure}

The authors report no disclosures relevant to the manuscript. Go to Neurology.org/ $\mathrm{N}$ for full disclosures.

\section{Publication history}

Received by Neurology November 10, 2018. Accepted in final form July 30, 2019.

Appendix Authors

\begin{tabular}{|c|c|c|c|}
\hline Name & Location & Role & Contribution \\
\hline $\begin{array}{l}\text { Joseph C. } \\
\text { Masdeu, MD, } \\
\text { PhD, FAAN }\end{array}$ & $\begin{array}{l}\text { Houston Methodist } \\
\text { Neurologic Institute, } \\
\text { TX; Weill Cornell } \\
\text { Medicine, New York, } \\
\text { NY }\end{array}$ & Author & $\begin{array}{l}\text { Prepared the first } \\
\text { draft, incorporated } \\
\text { the revisions from } \\
\text { the coauthors }\end{array}$ \\
\hline $\begin{array}{l}\text { Allen J. } \\
\text { Aksamit, MD, } \\
\text { FAAN }\end{array}$ & $\begin{array}{l}\text { Mayo Clinic, } \\
\text { Rochester, MN }\end{array}$ & Author & $\begin{array}{l}\text { Revised the } \\
\text { manuscript for } \\
\text { intellectual content }\end{array}$ \\
\hline $\begin{array}{l}\text { Alan C. Carver, } \\
\text { MD }\end{array}$ & $\begin{array}{l}\text { Memorial Sloan } \\
\text { Kettering Cancer } \\
\text { Center and Weill } \\
\text { Cornell Medicine, } \\
\text { New York, NY }\end{array}$ & Author & $\begin{array}{l}\text { Revised the } \\
\text { manuscript for } \\
\text { intellectual content }\end{array}$ \\
\hline $\begin{array}{l}\text { Kathleen M. } \\
\text { Foley, MD, } \\
\text { FAAN }\end{array}$ & $\begin{array}{l}\text { Memorial Sloan } \\
\text { Kettering Cancer } \\
\text { Center and Weill } \\
\text { Cornell Medicine, } \\
\text { New York, NY }\end{array}$ & Author & $\begin{array}{l}\text { Revised the } \\
\text { manuscript for } \\
\text { intellectual content }\end{array}$ \\
\hline
\end{tabular}

Appendix (continued)

\begin{tabular}{|c|c|c|c|}
\hline Name & Location & Role & Contribution \\
\hline $\begin{array}{l}\text { Joseph S. Kass, } \\
\text { MD, JD, FAAN }\end{array}$ & $\begin{array}{l}\text { Baylor College of } \\
\text { Medicine, Houston, } \\
\text { TX }\end{array}$ & Author & $\begin{array}{l}\text { Revised the } \\
\text { manuscript for } \\
\text { intellectual content }\end{array}$ \\
\hline $\begin{array}{l}\text { Raymond A. } \\
\text { Martin, MD, } \\
\text { FAAN }\end{array}$ & $\begin{array}{l}\text { McGovern Medical } \\
\text { School, University of } \\
\text { Texas Health Science } \\
\text { Center at Houston }\end{array}$ & Author & $\begin{array}{l}\text { Revised the } \\
\text { manuscript for } \\
\text { intellectual content }\end{array}$ \\
\hline $\begin{array}{l}\text { Elizabeth A. } \\
\text { McCusker, } \\
\text { MB, BS (Hons), } \\
\text { FRACP, FAAN }\end{array}$ & $\begin{array}{l}\text { Sydney University } \\
\text { Medical School, } \\
\text { Australia }\end{array}$ & Author & $\begin{array}{l}\text { Revised the } \\
\text { manuscript for } \\
\text { intellectual content }\end{array}$ \\
\hline $\begin{array}{l}\text { Michael P. } \\
\text { McQuillen, } \\
\text { MD, MA, FAAN }\end{array}$ & $\begin{array}{l}\text { Stanford Health } \\
\text { Care, Palo Alto, CA }\end{array}$ & Author & $\begin{array}{l}\text { Revised the } \\
\text { manuscript for } \\
\text { intellectual content }\end{array}$ \\
\hline $\begin{array}{l}\text { Raja } \\
\text { Mehanna, MD }\end{array}$ & $\begin{array}{l}\text { McGovern Medical } \\
\text { School, University of } \\
\text { Texas Health Science } \\
\text { Center at Houston }\end{array}$ & Author & $\begin{array}{l}\text { Revised the } \\
\text { manuscript for } \\
\text { intellectual content }\end{array}$ \\
\hline $\begin{array}{l}\text { Richard } \\
\text { Payne, MD }\end{array}$ & $\begin{array}{l}\text { Deceased; Formerly } \\
\text { at Duke University, } \\
\text { Durham, NC }\end{array}$ & Author & $\begin{array}{l}\text { Revised the } \\
\text { manuscript for } \\
\text { intellectual content }\end{array}$ \\
\hline $\begin{array}{l}\text { Stephen J. } \\
\text { Victor, MD, } \\
\text { FAAN }\end{array}$ & $\begin{array}{l}\text { Private practice, } \\
\text { Erwinna, PA }\end{array}$ & Author & $\begin{array}{l}\text { Revised the } \\
\text { manuscript for } \\
\text { intellectual content }\end{array}$ \\
\hline $\begin{array}{l}\text { Steven } \\
\text { Warach, MD, } \\
\text { PhD }\end{array}$ & $\begin{array}{l}\text { Dell Medical School, } \\
\text { University of Texas } \\
\text { at Austin }\end{array}$ & Author & $\begin{array}{l}\text { Revised the } \\
\text { manuscript for } \\
\text { intellectual content }\end{array}$ \\
\hline
\end{tabular}

\section{References}

1. Russell JA, Epstein LG, Bonnie RJ, et al. Lawful physician-hastened death: AAN position statement. Neurology 2018;90:420-422.

2. Budziszewski J. The Revenge of Conscience: Politics and the Fall of Man. Eugene: Wipf and Stock; 2010.

3. Caplan AL. Too hard to face. J Am Acad Psychiatry Law 2005;33:394-400.

4. Kant I. The Metaphysical Elements of Ethics [online]. Available at: gutenberg.org/ files/5684/5684-h/5684-h.htm\#link2H_4_0022. Accessed May 25, 2019.

5. Ingelfinger FJ. Arrogance. N Engl J Med 1980;303:1507-1511.

6. Snyder Sulmasy L, Mueller PS, Ethics P, Human Rights Committee of the American College of Physicians. Ethics and the legalization of physician-assisted suicide: an American College of Physicians position paper. Ann Intern Med 2017;167:576-578.

7. Okninski ME. Commentary on undue influence provisions under Oregon Death with Dignity Act and California's End of Life Option Act. J Law Med 2017;25: 77-85.

8. Onwuteaka-Philipsen BD, Brinkman-Stoppelenburg A, Penning C, de Jong-Krul GJ, van Delden JJ, van der Heide A. Trends in end-of-life practices before and after the enactment of the euthanasia law in The Netherlands from 1990 to 2010: a repeated cross-sectional survey. Lancet 2012;380:908-915.

9. Emanuel EJ, Onwuteaka-Philipsen BD, Urwin JW, Cohen J. Attitudes and practices of euthanasia and physician-assisted suicide in the United States, Canada, and Europe. JAMA 2016;316:79-90.

10. Cohen-Almagor R. Non-voluntary and involuntary euthanasia in The Netherlands: Dutch perspectives. Issues Law Med 2003;18:239-257.

11. A piece of my mind: It's over, Debbie. JAMA 1988;259:272.

12. Hedberg K, New C. Oregon's Death With Dignity Act: 20 years of experience to inform the debate. Ann Intern Med 2017;167:579-583.

13. Preston R. Death on demand? An analysis of physician-administered euthanasia in The Netherlands. Br Med Bull 2018;125:145-155.

14. Miller FG, Appelbaum PS. Physician-assisted death for psychiatric patients: misguided public policy. N Engl J Med 2018;378:883-885.

15. Vandenberghe J. Physician-assisted suicide and psychiatric illness. N Engl J Med 2018; 378:885-887.

16. Rehm D. Let dying people end their suffering. New York Times Jun 7, 2018.

17. Li M, Watt S, Escaf M, et al. Medical assistance in dying: implementing a hospitalbased program in Canada. N Engl J Med 2017;376:2082-2088.

18. Oregon Health Authority, Center for Health Statistics. Oregon Death with Dignity Act 2018, data summary [online]. Available at: https://www.oregon.gov/ oha/PH/PROVIDERPARTNERRESOURCES/EVALUATIONRESEARCH/ DEATHWITHDIGNITYACT/Documents/year21.pdf. Accessed March 16, 2019. 
19. Davies N, Maio L, van Riet Paap J, et al. Quality palliative care for cancer and dementia in five European countries: some common challenges. Aging Ment Health 2014;18: 400-410.

20. Penders YW, Onwuteaka-Philipsen B, Moreels S, et al. Differences in primary palliative care between people with organ failure and people with cancer: an international mortality follow-back study using quality indicators. Palliat Med 2018; 32:1498-1508.

21. Blikshavn T, Husum TL, Magelssen M. Four reasons why assisted dying should not be offered for depression. J Bioeth Inq 2017;14:151-157.

22. Ganzini L, Goy ER, Dobscha SK. Prevalence of depression and anxiety in patients requesting physicians' aid in dying: cross sectional survey. BMJ 2008;337:a1682.

23. Chochinov HM. Dignity and the essence of medicine: the A, B, C, and D of dignity conserving care. BMJ 2007;335:184-187.

24. Gamondi C, Pott M, Forbes K, Payne S. Exploring the experiences of bereaved families involved in assisted suicide in Southern Switzerland: a qualitative study. BMJ Support Palliat Care 2015;5:146-152.

25. Alexander L. Medical science under dictatorship. N Engl J Med 1949;241:39-47.

26. Grant T. I was my husband's caregiver as he was dying of cancer: it was the best seven months of my life. Washington Post August 30, 2016.
27. Sprung CL, Somerville MA, Radbruch L, et al. Physician-assisted suicide and euthanasia: emerging issues from a global perspective. J Palliat Care 2018;33:197-203.

28. Merriam-Webster. Suicide [online]. Available at: merriamwebster.com/dictionary/ suicide. Accessed March 23, 2019.

29. Antoniou SA, Antoniou GA, Granderath FA, Mavroforou A, Giannoukas AD, Antoniou AI. Reflections of the Hippocratic oath in modern medicine. World J Surg 2010;34:3075-3079.

30. Sulmasy DP, Finlay I, Fitzgerald F, Foley K, Payne R, Siegler M. Physician-assisted suicide: why neutrality by organized medicine is neither neutral nor appropriate. J Gen Intern Med 2018;33:1394-1399.

31. Trachtenberg AJ, Manns B. Cost analysis of medical assistance in dying in Canada. CMAJ 2017;189:E101-E105.

32. Stahl RY, Emanuel EJ. Physicians, not conscripts: conscientious objection in health care. N Engl J Med 2017;376:1380-1385.

33. Singer P. Practical Ethics, 3rd ed. New York: Cambridge University Press; 2011.

34. Parkinson C. Parkinson's Law and Other Studies in Administration. Boston: Houghton Mifflin Company; 1957.

35. Shampain P. Committee dynamics: part I: medical staff committees: you are entering the "twilight zone." QRC Advis 1989;5:1-6. 


\title{
Neurology
}

\author{
End of life: Expert care and support, not physician-hastened death \\ Joseph C. Masdeu, Allen J. Aksamit, Alan C. Carver, et al. \\ Neurology 2019;93;729-734 Published Online before print September 17, 2019 \\ DOI 10.1212/WNL.0000000000008356
}

This information is current as of September 17, 2019

Updated Information \&

Services

References

Subspecialty Collections

Permissions \& Licensing

Reprints including high resolution figures, can be found at:

http://n.neurology.org/content/93/17/729.full

This article cites 27 articles, 6 of which you can access for free at: http://n.neurology.org/content/93/17/729.full\#ref-list-1

This article, along with others on similar topics, appears in the following collection(s):

All Ethics in Neurology/Legal issues

http://n.neurology.org/cgi/collection/all_ethics_in_neurology_legal_iss ues

Palliative care

http://n.neurology.org/cgi/collection/palliative_care

Professional conduct and ethics

http://n.neurology.org/cgi/collection/professional_conduct_and_ethics

Information about reproducing this article in parts (figures,tables) or in its entirety can be found online at:

http://www.neurology.org/about/about_the_journal\#permissions

Information about ordering reprints can be found online:

http://n.neurology.org/subscribers/advertise

Neurology ${ }^{\circledR}$ is the official journal of the American Academy of Neurology. Published continuously since 1951, it is now a weekly with 48 issues per year. Copyright Copyright ( 2019 The Author(s). Published by Wolters Kluwer Health, Inc. on behalf of the American Academy of Neurology.. All rights reserved. Print ISSN: 0028-3878. Online ISSN: 1526-632X.

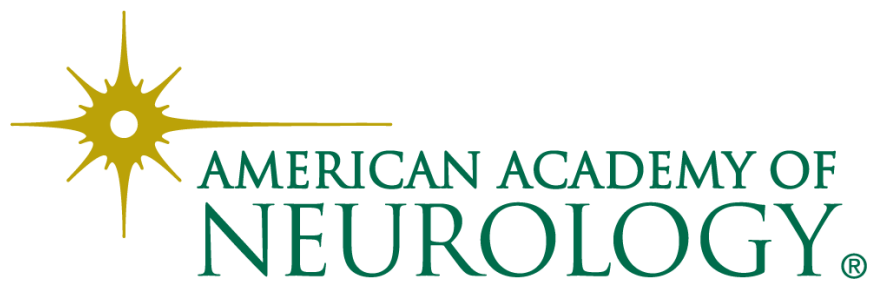

